\title{
Medical Disorders of Pregnancy among Inpatients at a Tertiary Level Hospital
}

\author{
Baral G' ${ }^{1}$, Joshi $\mathbf{R}^{1}$, Subba $\mathbf{P}^{1}$, Pokhrel $\mathbf{S}^{\mathbf{1}}, \mathbf{K C ~ S} \mathbf{S}^{\mathbf{1}}$, Baree $\mathbf{Z A}^{\mathbf{1}}$ \\ ${ }^{1}$ Department of Obstetrics and Gynecology, Paropakar Maternity and Women's Hospital, Thapathali, Kathmandu
}

Received: 23-Jan-2017; Accepted: 30-Mar-2017

\begin{abstract}
Aims: The aim of the study was to determine the pattern of medical disorders in admitted pregnant women.
Methods: A descriptive retrospective study was conducted for a year at Paropakar Maternity and Women's Hospital in Kathmandu in 2016.

Results: In a year of $2016,2.4 \%$ of 20521 pregnant women admitted had medical disorder with $87 \%$ at optimal age of reproduction (20-35 years). The commonest disorders were hypertensive disease of pregnancy $(68 \%)$, urinary tract infection $(11 \%)$, other infectious conditions $(5 \%)$, thyroid disorder $(5 \%)$, diabetic complications $(2 \%)$ and cardiac disease $(0.4 \%)$.
\end{abstract}

Conclusions: Hypertensive disorder is predominant medical disorder of pregnancy followed by urinary tract infection, endocrine disorder and viral infections in order.

Keywords: hypertension, medical disorder, Paropakar, pregnancy

DOI: http://dx.doi.org/10.3126/njog.v12i1.18974

\section{INTRODUCTION}

Pregnancy is a physiological state which can be complicated by many medical and surgical disorders. Physiological changes occurring during pregnancy are essential for the successful outcome of pregnancy. Medical disorders may interfere with these adaptations and complicate the pregnancy. In some conditions, pregnancy is contraindicated while in others early termination may be warranted for the health of mother and fetus. Pregnancy itself can also have an adverse impact in the preexisting or new onset medical conditions. Eighty percent of maternal mortality is due to the direct causes while $20 \%$ are the result of pre-existing conditions that are exacerbated by pregnancy or its management. ${ }^{1}$ In a confidential inquiries in maternal deaths, two thirds of mothers died from medical and mental health problems and three quarters of them had pre-existing medical or mental health problems. ${ }^{2}$ Over past years maternal mortality have decreased worldwide. ${ }^{3}$ In comparison to the developed nations, it is still higher in developing countries. $^{1,3}$ The burden of non-communicable

\section{CORRESPONDENCE}

Dr Gehanath Baral,

Professor of Obstetrics and Gynecology.

Cell: +977-9841228829.

Email: gehanath@gmail.com. disease like heart disease, chronic respiratory disease and diabetes are in increasing trend in the low and middle income countries. ${ }^{4}$ Previously, any medical disorders during pregnancy had a much worse outcome in terms of both maternal and fetal health. With the advancement in all the sectors especially in maternal/fetal medicine, obstetric anesthesia and pediatrics, more fruitful outcome can be anticipated even in pregnancies with the medical disorders. In a study done in Nigeria, the incidence of medical disorders among pregnant women was $16 \% .^{5}$ In the context of absence of similar studies in our part, this study aims to find out the magnitude and types of medical disorders during pregnancy.

\section{METHODS}

This is a retrospective study done in Paropakar Maternity and Women's Hospital, Nepal. It is a tertiary referral centre and country's largest maternity hospital. Information was collected from the admission room record of the hospital from January to December 2016 as a census. Socio-demographic information, gravid, parity, gestational age at presentation and type of disorder were recorded for the pregnancies with medical disorders. For the cases with multiple diagnoses, the primary diagnosis was taken and other associated disorders also noted. Ethical clearance was taken from the hospital research committee prior to the data collection. Data were entered into the SPSS 
16 and descriptive statistics generated.

\section{RESULTS}

During the study period out of 20521 pregnant women admitted, 494 (2.4\%) had medical disorders. The age ranged from 17 to 43 years with the mean age of 27.1 years. Peak incidence $(86.8 \%, 429)$ was seen at the optimal age of reproduction (20-35 years) while $13.2 \%$ (65) were in the extremes of ages (figure $1)$. More than two third of women were multi-gravida and majority of the women (238) were admitted at their second pregnancy. Two fourth women were primipara while one fourth of the women were nullipara and few (10) were grand multipara (figure 2). Three fourth of the pregnant women were at the third trimester at the time of admission while nearly one sixth were post date and slightly over one percent were post term (figure 3).

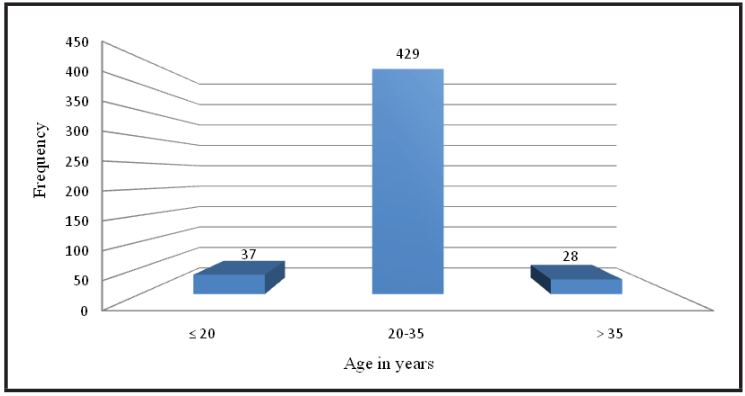

Figure 1. Age distribution

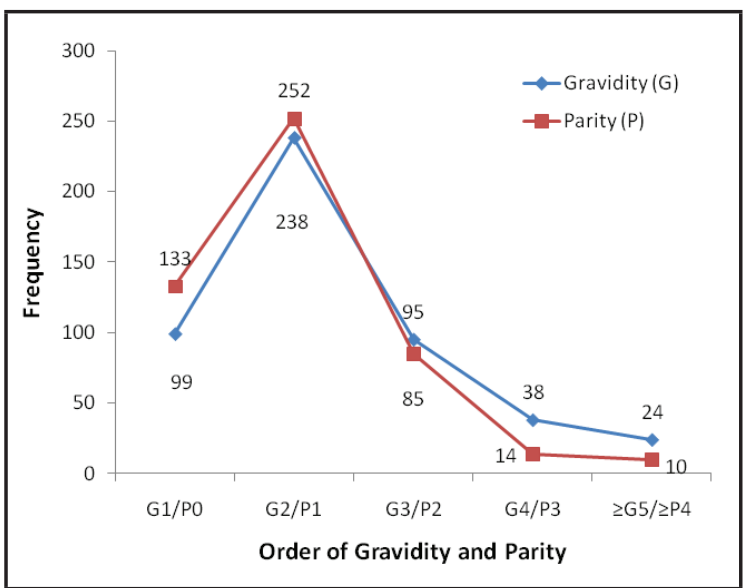

Figure-2. Gravida and Parity distribution

Hypertensive disorders were the commonest (68.2\%, 337) medical cause for admission among the pregnant women (figure 4). Majority of them had gestational hypertension (218) while pre-eclampsia was seen in 74 women and a few (seven) of them were admitted with eclampsia (table 1). Pre-existing chronic hypertension was seen among 38 women and two of them had superimposed pre-eclampsia. Renal and urinary tract disorders were the second (54) leading cause for admission (figure 5).

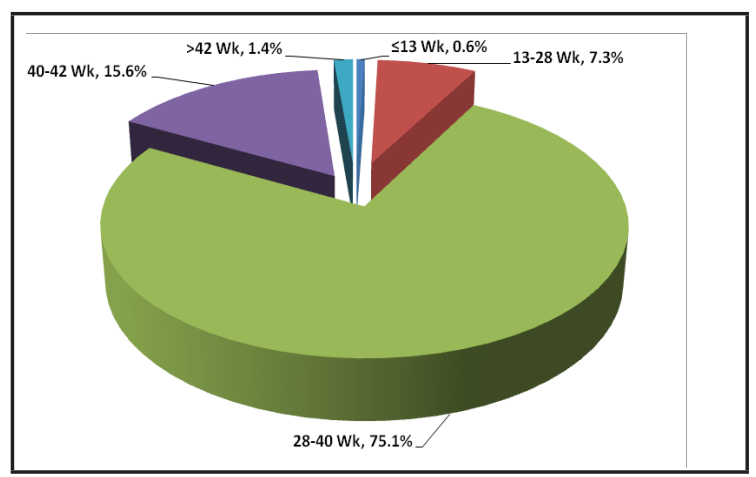

Figure 3: Gestational age at the time of admission

Urinary tract infections (37) and pyelonephritis (16) accounted for about $11 \%$ of all the medical disorders during the study period (table 1). About five percent of women were admitted with other infectious diseases and majority (14) among them had HBsAg positive status (figure 5 and table 1). Four women each had chicken pox and HIV positive status at the time of admission (table 1). Twenty-three (five percent) pregnant women had hypothyroidism while Graves's disease was seen in one woman during the study period (table 1). Respiratory disorders were seen among 16 women among whom upper respiratory tract infection (11) was the commonest one followed by asthma (table 1). Among the nine cases of diabetes with pregnancy two-third of them had gestational diabetes mellitus while rest had overt diabetes (table 1). Acute gastro-enteritis necessitating admission was found among eight pregnant women. Anemia was seen in six cases while four cases each had epilepsy and dermatological problem (table 1). Cardiac disease was seen in 2 women at admission and one woman had psychiatric disorder during the study period.

Table 1. Types of medical disorders in pregnancy

\begin{tabular}{|lll|}
\hline \multicolumn{1}{|l}{ Medical Disorders } & Frequency \\
\hline & $\begin{array}{l}\text { Gestational } \\
\text { Hypertension }\end{array}$ & 218 \\
Hypertensive & $\begin{array}{l}\text { Pre-eclampsia } \\
(68.2 \%, 337)\end{array}$ & 74 \\
& $\begin{array}{l}\text { Chronic } \\
\text { Hypertension }\end{array}$ & 38 \\
& Eclampsia & 7
\end{tabular}




\begin{tabular}{|c|c|c|}
\hline \multirow{3}{*}{$\begin{array}{l}\text { Renal and } \\
\text { Urinary tract } \\
(10.9 \%, 54)\end{array}$} & UTI & 37 \\
\hline & Pyelonephritis & 16 \\
\hline & Nephritis & 1 \\
\hline \multirow{3}{*}{$\begin{array}{l}\text { Respiratory } \\
\text { tract }(3.2 \%, 16)\end{array}$} & LRTI & 2 \\
\hline & URTI & 11 \\
\hline & Asthma & 3 \\
\hline \multirow{2}{*}{$\begin{array}{l}\text { Diabetes } \\
(1.8 \%, 9)\end{array}$} & GDM & 6 \\
\hline & Overt DM & 3 \\
\hline \multirow{2}{*}{$\begin{array}{l}\text { Endocrine } \\
(4.8 \%, 24)\end{array}$} & Hypothyroidism & 23 \\
\hline & Graves disease & 1 \\
\hline \multirow{3}{*}{$\begin{array}{l}\text { Hematological } \\
(1.6 \%, 8)\end{array}$} & Anemia & 6 \\
\hline & DIC & 1 \\
\hline & Thrombocytopenia & 1 \\
\hline \multirow{7}{*}{$\begin{array}{l}\text { Infectious } \\
(5.2 \%, 26)\end{array}$} & Hepatitis B & 14 \\
\hline & Chicken pox & 4 \\
\hline & Herpes Zooster & 1 \\
\hline & HIV & 4 \\
\hline & Measles & 1 \\
\hline & Syphilis & 1 \\
\hline & TB & 1 \\
\hline \multirow{2}{*}{$\begin{array}{l}\text { Gastrointestinal } \\
(1.8 \%, 9)\end{array}$} & AGE & 8 \\
\hline & APD & 1 \\
\hline \multirow{2}{*}{$\begin{array}{l}\text { Dermatological } \\
(0.8 \%, 4)\end{array}$} & Pururitis gravidarum & 1 \\
\hline & $\begin{array}{l}\text { Cholestasis of } \\
\text { pregnancy }\end{array}$ & 3 \\
\hline \multirow{2}{*}{$\begin{array}{l}\text { Cardiac }(0.4 \% \text {, } \\
\text { 2) }\end{array}$} & Cardiac Disease & 1 \\
\hline & RHD & 1 \\
\hline $\begin{array}{l}\text { Neurological } \\
(0.8 \%, 4)\end{array}$ & Epilepsy & 4 \\
\hline $\begin{array}{l}\text { Psychiatric } \\
(0.2 \%, 1)\end{array}$ & Psychiatric illness & 1 \\
\hline Total & & 494 \\
\hline
\end{tabular}

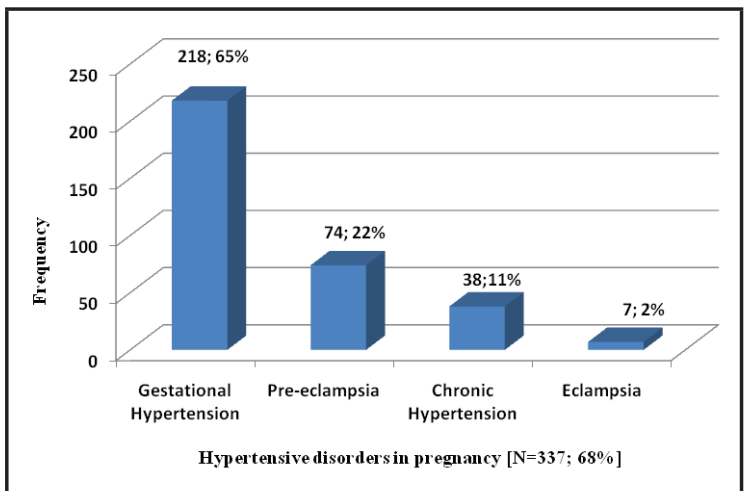

Figure 4. Subtypes of hypertensive disorder of pregnancy

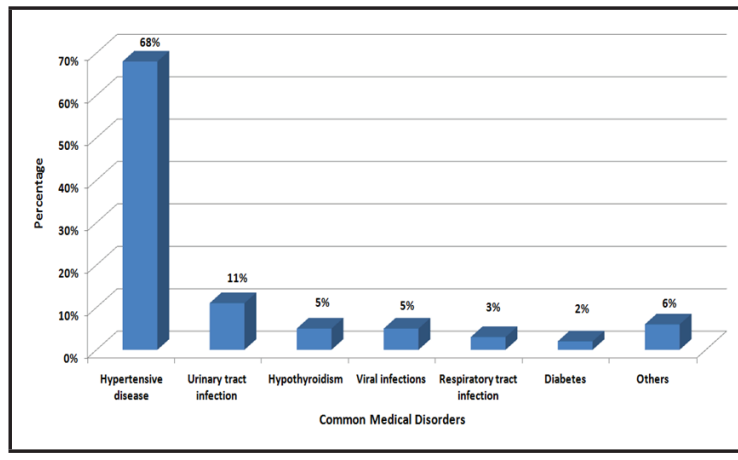

Figure 5. Medical disorders in pregnancy

\section{DISCUSSION}

The incidence of medical disorders in this study was $2.4 \%$ compared to the study done by Agwu et al..$^{5}$ In this study, hypertensive disorders was the commonest disorder while in the Nigerian study hypertensive disorder was second to the malarial infection which could be due to higher prevalence of malaria in Nigeria. ${ }^{5}$ In a multi-centric study done in China, severe pre-eclampsia was the commonest while in this study pre-eclampsia was second to the gestational hypertension. ${ }^{6}$ Eclampsia was the least common one among the hypertensive disorders similar to other studies. ${ }^{5,6}$

Urinary tract infection is the second most common medical disorder in this study which is comparable to the Nigerian study. ${ }^{5}$ This signifies the necessity to screen the pregnant women for asymptomatic bacteriuria. Higher incidence of pyelonephritis (3.2\%) in pregnancy is found in this study whereas a six years database study done in Jamaica found 102 cases ( $0.7 \%$ of deliveries). ${ }^{7}$ Hepatitis B infection diagnosed by the presence of the surface antigen is found to be most common type among the infectious medical disorders. A five year record in Patan Hospital where out of $136(0.3 \%)$ HBsAg positive cases only 32 pregnant women were recorded as positive. ${ }^{8}$ Acute gastroenterirtis was the main reason for admission eight $(1.6 \%)$ women in this study whereas $6 \%$ of 128 pregnant women admitted for pain abdomen had acute gastroenteritis in a study done in Bangladesh. ${ }^{9}$ Higher incidence of hypothyroidism is seen in this study which is similar to two year study done in 1000 pregnant women where 116 had thyroid disorders. ${ }^{10}$ Anemia necessitating admission was found in six cases in this study which is less compared to the other studies which had included all severities of anemia. ${ }^{11,12}$ In a six year study done in Iran, they 
found 50 cases of pregnancy with epilepsy and the absolute number is double than this study (four in a year).$^{13}$ Cardiac disease during pregnancy in this study is much less compared to a study done in India, where 59 cardiac cases out of 7053 deliveries was found. ${ }^{14}$ Intra-hepatic cholestasis of pregnancy was seen in three cases at the time of admission which is comparable to the average incidence (less than one percent) in Asian population. ${ }^{15}$

\section{CONCLUSIONS}

Hypertensive disorders in pregnancy are the most common medical disorder followed by renal and urinary tract infections. Infectious diseases and endocrine disorders also affect pregnancy. Endocrine disorders and viral infections are the third common group of medical disorder. Pregnancy management, therefore, requires multidisciplinary intervention for better outcome.

\section{REFERENCES}

1. Reduction of maternal mortality: a joint WHO/UNFPA/ UNICEF/World Bank statement. . Switzerland :WHO;1999. ISBN 9241561955

2. Knight M, Kenyon S, Brocklehurst P, Neilson J, Shakespeare J, Kurinczuk JJ (Eds.) on behalf of MBRRACE-UK. Saving lives, improving mothers' care - lessons learned to inform future maternity care from the UK and Ireland confidential enquiries into maternal deaths and morbidity 2009-12. Oxford: National Perinatal Epidemiology Unit, University of Oxford;2014

3. Trends in maternal mortality: 1990 to 2013. Estimates by WHO, UNICEF, UNFPA. The World Bank and the United Nations Population Division;2014. ISBN 9789241507226

4. Global status report on non-communicable diseases. Italy: WHO; 2010. ISBN 9789240686458.

5. Agwu UM, Ifebunandu N, Obuna JA, Nworie CE, Nwokpo OS, Joannes Umeora OU. Prevalence of medical disorders in pregnancy in Ebonyi State University Teaching Hospital. J Basic Clin Reprod Sci. 2013;2:22-6

6. Ye C, Ruan Y, Zou L, Li G, Li C, Yi C et al. The 2011 survey on hypertensive disorders of pregnancy in China: prevalence, risk factors, complications, pregnancy and perinatal outcomes. PLOS ONE. 2014; 9(6): e100180. doi:10.1371/ journal.pone. 0100180

7. Dawkins JC, Fletcher HM, Rattray GA, Reid M, GordonStrachan G. Acute pyelonephritis in pregnancy: a retrospective descriptive hospital based-study. ISRN Obstet Gynecol.2012; 6. doi:10.5402/2012/519321
8. Ansari I. Hepatitis B and HIV in children and pregnant ladies at Patan Hospital. J PAHS. 2014;1(1):26-9.

9. Haque M, Kamal F; Chowdhury S; Moniruzzaman; Aziz I. Non obstetric causes and presentation of acute abdomen among the pregnant women. J Fam Reprod Health. 2014;8(3):117-22

10. Saraladevi R, Nirmala Kumari T, Shreen B, Usha Rani V. Prevalence of thyroid disorder in pregnancy and pregnancy outcome. IAIM. 2016;3(3):1-11.

11. Singh $\mathrm{P}, \mathrm{Khan} \mathrm{S}$, Mittal RK. Anemia during pregnancy in the women of western Nepal .Bali Med J. 2013;2(1):14-6.

12. Raut BK, Jha MK, Shrestha A, Sah A, Sapkota A, Byanju S, Malla SS. et al. Prevalence of iron deficiency anemia among pregnant women before iron supplementation in Kathmandu university Hospital/ Dhulikhel Hospital. J Gynecol Obstet. 2014;2(4):54-8.

13. Fatemeh M, Nazanin EB. Pregnancy complications and outcomes in women with epilepsy. Open J Obstet Gynecol. 2012;2: 230-4. http://dx.doi.org/10.4236/ojog.2012.23047 Published Online September 2012 (http://www.SciRP.org/ journal/ojog/)

14. Shah TM, Mishra K, Ninama P, Parikh C. Diseases with pregnancy - a study of maternal and fetal outcome. IAIM. 2015;2(1);22-9.

15. Pusl T, Beuers U. Intrahepatic cholestasis of pregnancy. Orphanet J Rare Diseases. 2007; 2:26. doi:10.1186/1750$1172-2-26$ 